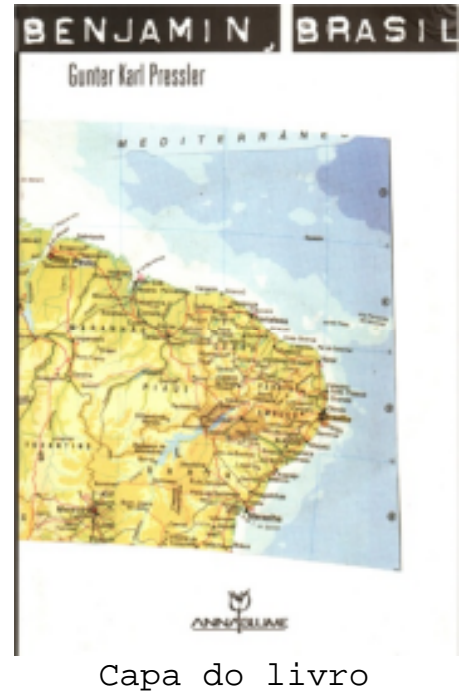

\title{
Leituras de Benjamin e intelectualidade brasileira
}

\author{
Maria Antonieta Pereira \\ Coordenadora Geral do Programa A tela e o texto.
}

\begin{abstract}
PRESSLER, Gunter Karl. Benjamin, Brasil - a recepção de Walter Benjamin, de 1960 a 2005: um estudo sobre a formação da intelectualidade brasileira. São Paulo: Annablume, 2006. 406 p.
\end{abstract}

A alentada obra de Gunter K. Pressler encerra um minucioso exame de quase meio século de recepção da obra de Walter Benjamin por parte dos intelectuais brasileiros. Como epígrafe inicial do estudo, encontramos uma frase de Auerbach a Benjamin: "Há um ano pelo menos, quando se procurava um professor para ensinar literatura alemã em São Paulo, pensei no senhor." Pronunciada em Roma, nos idos de 1935, essa frase corrobora as muitas relações entre o pensamento benjaminiano e a literatura, articulando-os às leituras então desenvolvidas em território nacional.

Tendo como texto-base a tese de doutorado de Pressler (Benjamin, Brasil - a recepção de Walter Benjamin no Brasil, USP/1995), a obra desenvolve ampla coleta e minuciosa análise de dados, no mapeamento dos robustos diálogos desenvolvidos entre os textos benjaminianos e certos escritores-críticos ou pensadores nacionais. Autores como Moacyr Scliar, Haroldo de Campos, Roberto Schwarz, Leandro Konder, Sérgio Paulo Rouanet 
e Willi Bolle expressam sua visão pessoal a respeito da produção benjaminiana, contribuindo para desenhar o quadro de sua leitura no país. Nas 16 entrevistas realizadas, encontramos uma grande varidade de temas e pontos de vista, além de muitos dados sobre a história da leitura de Benjamin e autores correlatos no Brasil e no mundo.

Nesse cenário, os principais objetivos do estudo de Pressler são

- documentar e mostrar o material completo da obra traduzida de Walter Benjamin e da literatura crítica;

- analisar e interpretar os fatos dentro do tempo e do espaço específicos nas últimas quatro décadas;

- caracterizar sua influência na formação da intelectualidade brasileira e

- levantar a contribuição da crítica brasileira para a interpretação benjaminiana em geral.

Essas metas indicam não só a intenção de mapear os diversos temas provocados pelo pensador frankfurtiano - não é casual o fato de a capa do livro ser um mapa do Brasil devidamente fragmentado - mas também o desejo de aprofundar o conhecimento sobre a constituição de um pensamento crítico nacional.

Nessa perspectiva, são revisitados alguns ensaios do autor, tais como "O narrador - considerações sobre a obra de Nikolai Leskov", "Teses sobre a Filosofia da História", "A obra de arte na era de sua reprodutibilidade técnica" e "Paris, capital do século XIX" que, segundo Pressler, contribuíram para configurar as 4 fases das leituras brasileiras de Benjamin, a saber:

$1^{a}$ - A obra de arte na era de sua reprodutibilidade técnica $(1960 / 1974)$

2a. - O teórico da Modernidade (1975-1984)

$3^{a}$. - Obras escolhidas (1985-1990)

$4^{\text {a. }}$ - Obras das Passagens (1991-2005)

A leitura sistemática de Benjamin, por gerações e gerações de estudiosos brasileiros, contribuiu para que os debates relativos à recepção se estabelecessem em forte articulação com as teorias da tradução, como denota a própria idéia de transcriação cunhada por Haroldo de Campos. Identificando as diferentes fases da recepção de Benjamin no Brasil, Gunter Pressler mostra sua difusão dentro de variadas perspectivas: como estética marxista, como teoria sobre a Modernidade e a Pós-Modernidade ou presidindo proposições de vertente historiográfica. Mais tarde, outras leituras viriam fundamentar teorias da narração e inesgotáveis debates sobre 
gêneros, vida urbana, relações entre imagens/textos, humanidade/máquina, novidade/memória.

Além de estabelecer uma ampla discussão sobre a obra benjaminiana, a partir de pontos de vista que a utilizaram para se constituírem e, ao mesmo tempo, estabeleceram novas possibilidades de recebê-la, o livro de Pressler também se faz acompanhar por um $\mathrm{CD}$, por meio do qual o leitor pode ouvir entrevistas realizadas durante a pesquisa e contemplar imagens de publicações que indicam a presença de Benjamin no cenário brasileiro desde os anos 60. Um vídeo de abertura mostra Benedito Nunes - que é também o apresentador da obra comentando seus primeiros contatos com a idéia de perda da aura, em Obras escolhidas, numa tradução do alemão para o francês. Segundo Nunes, desde cedo, chamaram-lhe a atenção os temas baudelairianos e o debate sobre a reprodutibilidade da obra de arte. No CD, o leitor também irá encontrar fragmentos de $<=" \| \quad i="$ " que podem ser lidos na tela do computador a partir de páginas interativas.

No lugar do resumo, Gunter premia o leitor com um soneto intitulado BEBRA (sigla formada pelas primeirs letras das palavras "Benjamin" e "Brasil"). Nesse poema, o autor busca, por um lado, sintetizar certas proposições básicas do pensamento de Benjamin e, por outro, destacar sua estreita relação com a arte literária. Em companhia de Freud, Mallarmé e Baudelaire, o leitor deve cruzar a porta de entrada da obra - a poesia - e alcançar o pensamento crítico que se encontra lá dentro. Gesto que, sem dúvida, caracteriza Benjamin e também alguns benjaminianos como Gunter Pressler.

\section{BEBRA}

Estética marxista e arte

Pensando com Baudelaire

Ontologicamente ou não

Finda em Mallarmé

Estética frankfurtiana e sociedade

Pensando com Freud

Politicamente ou não

Resulta em alegoria

Origem e futuro

Historicamente lido

No presente

Novas leituras são

Interpretações in tempus

Imagens e narrativas 